University of Nebraska - Lincoln

DigitalCommons@University of Nebraska - Lincoln

1982

\title{
CHROMOSOME NUMBERS OF RELEASED CULTIVARS OF SWITCHGRASS, INDIANGRASS, BIG BLUESTEM, AND SAND BLUESTEM
}

\author{
R. D. Riley \\ Pioneer Hi-Bred Int., Inc. \\ Kenneth P. Vogel \\ University of Nebraska-Lincoln, kvogel1@unl.edu
}

Follow this and additional works at: https://digitalcommons.unl.edu/usdaarsfacpub

Riley, R. D. and Vogel, Kenneth P., "CHROMOSOME NUMBERS OF RELEASED CULTIVARS OF

SWITCHGRASS, INDIANGRASS, BIG BLUESTEM, AND SAND BLUESTEM" (1982). Publications from USDAARS / UNL Faculty. 1871.

https://digitalcommons.unl.edu/usdaarsfacpub/1871

This Article is brought to you for free and open access by the U.S. Department of Agriculture: Agricultural Research Service, Lincoln, Nebraska at DigitalCommons@University of Nebraska - Lincoln. It has been accepted for inclusion in Publications from USDA-ARS / UNL Faculty by an authorized administrator of DigitalCommons@University of Nebraska - Lincoln. 
4. Prasada Rao, K.E., and D.S. Murty. 1979. A basmati (scented) sorghum from Madhya Pradesh. Curr. Sci. 48:824-826.

5. Schertz, K.F., and J.C. Stephens. 1966. Compilation of gene symbols, recommended revision and summary of linkage for inherited characters of Sorghum vulgare Pers., Tech. Monograph 3, Texas Agric. Exp. Stn.

6. Sood, B.C., and E.A. Siddiq. 1978. A rapid technique for scent determination in rice. Indian J. Genet. 38:268-271.

\section{CHROMOSOME NUMBERS OF RELEASED GULTIVARS OF SWITCHGRASS, INDIANGRASS, BIG BLUESTEM, AND SAND BLUESTEM ${ }^{1}$}

\author{
R. D. Riley and K. P. Vogel ${ }^{2}$
}

\section{ABSTRACT}

Chromosome numbers of cultivars of switchgrass (Panicum virgatum L.), indiangrass (Sorghastrum nutans $\mathbf{L}$.) and the tall bluestem complex of big bluestem (Andropogon gerardi Vitman.) and sand bluestem (Andropogon hallii Hack.) were determined. Ploidy levels of these cultivars have not been reported previously even though these grasses have been reported to have two or more ploidy levels. Switchgrass cultivars 'Pathfinder', 'Blackwell', and 'Nebraska 28' were hexaploids $(2 \mathrm{n}=54)$, while 'Summer' and 'Kanlow' were tetraploids $(2 \mathrm{n}=36)$. Indiangrass cultivars 'Nebraska 54', 'Oto', 'Osage', and 'Holt' were all tetraploids $(2 \mathrm{n}=40)$. Big bluestem cultivars 'Pawnee' and 'Kaw' and the sand bluestem cultivar 'Goldstrike' were hexaploids $(2 \mathrm{n}=60)$. Meiosis was normal with bivalent pairing for most plants examined from all three grasses.

Additional index words: Panicum virgatum, Sorghastrum nutans, Andropogon gerardi, Andropogon hallii, Cytogenetics, Polyploids.

$\mathbf{T}$ HE more important native North American tallgrasses include switchgrass (Panicum virgatum L.), indiangrass (Sorghastrum nutans L.) and the tall bluestem complex of big bluestem (Andropogon geradi Vitman.) and sand bluestem (Andropogon hallii Hack.). These grasses are components of native rangeland and are also used for pastures and conservation plantings. Several cultivars of each of these grasses have been developed and released. These cultivars are valuable for commercial use, as germplasm in breeding programs, and in physiological and management studies.

Chromosome numbers of these cultivars have not been published even though all of these grasses have been reported to have two or more ploidy levels. In switchgrass, which has a basic chromosome number of $\mathrm{x}=9$, chromosome numbers of $18,36,54,72,90$, and 108 were reported by Nielsen (1944). Normal diploid pairing has usually occurred in switchgrass although some aneuploid variants and multivalent associations were reported at higher ploidy levels (Barnett and Carver, 1967). Gould (1975) listed indiangrass as having complements of 20,40, and 80 with 40 as the most common number. Saura (1948) reported $2 n=20$ for a South American indiangrass. Big

${ }^{1}$ Contribution from USDA/ARS and the Nebraska Agric. Exp. Stn Lincoln, Nebr. Published as Paper No. 6536, Journal Series, Nebr Agric. Exp. Stn. Part of a thesis submitted by R. D. Riley to the faculty of the Graduate College of the Univ. of Nebraska in partial fulfillment of the requirements for the M.S. degree

${ }^{2}$ Research station manager-plant breeder, Pioneer Hi-Bred Int., Inc,, P.O. Box 557, Algona, IA 50511, formerly graduate research assistant, Univ. of Nebraska, Lincoln, Nebr; research agronomist, USDA/ARS, Univ. of Nebraska, Lincoln, NE 68583.
Table 1. Chromosome numbers of switchgrass, indiangrass, and big and sand bluestem cultivars.

\begin{tabular}{llcc}
\hline Species & Cultivar & $\begin{array}{c}\text { Plants } \\
\text { examined }\end{array}$ & $\begin{array}{c}\text { Chromosomes } \\
\text { 2n }\end{array}$ \\
\cline { 3 - 4 } Switchgrass & Pathfinder & 12 & no. \\
& Blackwell & 12 & 54 \\
& Nebraska 28 & 7 & 54 \\
& Summer & 6 & 54 \\
Indiangrass & Kanlow & 7 & 36 \\
& Nebraska 54 & 8 & 40 \\
& Oto & 5 & 40 \\
Big bluestem & Osage & 5 & 40 \\
& Holt & 5 & 40 \\
Sand bluestem & Pawnee & 13 & 60 \\
& Kaw & 6 & 60 \\
\hline
\end{tabular}

and sand bluestem are referred to as the tall bluestem complex because they are quite similar, hybridize readily in breeding nurseries, and often intergrade in nature. Chromosome numbers of $2 \mathrm{n}=20$ (Love and Solbrig, 1964), 40, 60 (Church, 1940), 80 (Davidse and Pohl, 1972), and 100 (Brown, 1950) were reported. Most researchers have observed normal meiosis in indiangrass and the tall bluestems.

The purpose of this study was to determine the chromosome numbers of cultivars of these grasses that are being used in the Great Plains in order to make efficient use of these cultivars in research programs.

\section{MATERIALS AND METHODS}

Inflorescences were collected from plants grown in eastern Nebraska field nurseries or in pots in the greenhouse at Lincoln, Nebr. Inflorescences were fixed in Farmer's Fluid and pollen mother cells were squashed and stained with acetocarmine. Between 5 and 13 plants were examined for each cultivar. Preparations from each plant were examined, and a minimum of two chromosome counts per plant were made at diakinesis or Metaphase I. Slides were then scanned for the presence of any irregularities. The number of pollen mother cells observed for each plant was not recorded since chromosome irregularities were observed infrequently. All of the cultivars in Table 1 were described by Hanson (1972) except for 'Goldstrike' which was described by Newell (1973).

\section{RESULTS AND DISCUSSION}

Three of the switchgrasses were hexaploid while two were tetraploid (Table 1). The indiangrasses were tetraploid and all of the tall bluestems were hexaploid. Most cells had normal meiosis with bivalent pairing and regular segregation. Some abnormalities were found, however, particularly in one 'Holt' indiangrass plant which had some cells with lagging chromosomes and bridges. Most cells from the same plant were normal.

These results indicate that the cultivars studied behave meiotically as diploids although they are polyploids. Breeding methodology developed for cross-pollinated diploids such as maize ( $Z e a$ mays $\mathrm{L}$.) should be useful in improving these grasses.

The switchgrass cultivars 'Pathfinder', 'Blackwell', and 'Summer' may be very useful in studies to determine the 
effect of ploidy level on physiological processes, because they are similar in productivity and maturity.

\section{REFERENCES}

1. Barnett, F. L., and R. F. Carver. 1967. Meiosis and pollen stainability in switchgrass, Panicum virgatum L. Crop Sci. 7:301-304.

2. Brown, W. V. 1950. A cytological study of some Texas Gramineae. Bull. Torrey Bot, Club 77:63-76.

3. Church, G. L. 1940. Cytotaxonomic studies in the Gramineae Spartina, Andropogon, and Panicum. Am. J. Bot. 27:263-271.

4. Davidse, Gerrit, and R. W. Pohl. 1972. Chromosome numbers, meiotic behavior, and notes on some grasses from Central America and the West Indies. Can. J. Bot. 50:1441-1452.
5. Gould, F. W. 1975. The Grasses of Texas. Texas A \& M Univ. Press, College Station, Tex.

6. Hanson, A. A. 1972. Grass varieties in the United States. Agric. Handbook No. 170, USDA, ARS. U.S. Government Printing Office, Washington, D.C.

7. Love, Askell and O. T. Solbrig. 1964. IOPB chromosome number reports I. Taxon. 13:99-110.

8. Newell, L. C. 1973. Notice of release of Goldstrikes sand bluestem. Nebr. Agr. Exp. Stn. sand USDA, ARS.

9. Nielson, E. L. 1944. Analysis of variation in Panicum virgatum. J. Agric. Res. 69:327-353.

10. Saura, Fulgencio. 1948. Cariologia de Gramineae en Argentina. Agron. Vet., 12:51-67.

\section{Registration of Crop Cultivars}

\section{REGISTRATION OF AZURE BARLEY ${ }^{1}$}

(Reg. No. 179)

\section{A. E. Foster, J. D. Franckowiak, V. D. Pederson, and R. E. Pyler ${ }^{2}$}

'AzurE' barley (Hordeum vulgare L.), C.I. 15865, was developed by the North Dakota Agricultural Experiment Station in cooperation with USDA-ARS and was released $14 \mathrm{Jan}$. 1982. It was tested as ND1894 and traces to a bulk of $50 \mathrm{~F}_{10}$ head rows, made in 1978. Azure is derived from the cross 'Bonanza'//'Nordic'/ NDB130. The $F_{1}$ and $F_{3}$ generations of this cross were grown in the greenhouse and field, respectively, at Fargo, N. Dak., and the $\mathrm{F}_{2}$ and $\mathrm{F}_{4}$ generations were grown in a winter nursery at Ciudad Obregon, Sonora, Mexico.

Azure is a six-rowed, smooth-awned spring barley. The covered kernels are medium-sized and have a blue aleurone and long hairs on the rachilla. The spike is medium-long, mediumlax, and semi-erect. Azure is medium-early, mid-tall, and has moderately strong straw. Compared with Bonanza, it is slightly earlier, shorter, and more resistant to lodging. Azure is resistant to Puccinia graminis Pers. f. sp. tritici Eriks. and Henn. It shows more field resistance than Bonanza to prevalent strains of $\mathrm{Hel}$ minthosporium sativum Pamm., King., and Bakke., but less resistance than Bonanza to Pyrenophora teres (Died) Drechs. Azure is susceptible to Ustilago nuda (Jens.) Rostr. and $U$. hordei (Pers.) Lagerh. Azure has exceeded Bonanza in yield by $7 \%$ in 7 years of testing in North Dakota and is adapted to the barley growing regions of North Dakota, Minnesota, and South Dakota. The kernel plumpness of Azure exceeds that of Bonanza and their test weights are equal. Quality tests conducted by North Dakota State University, the USDA-ARS Barley and Malt Laboratory, Madison, Wis., and industry laboratories have shown that Azure is superior to Bonanza in total protein percentage (one percentage point lower) and equal in the ratio of soluble to total protein and in extract percentage. Azure is slightly lower than Bonanza in soluble protein, diastatic power, and alpha-amylase activity and slightly higher in fine-coarse grind extract difference. Azure has been classed as a cultivar recommended for malting and brewing by the Malting Barley Improvement Association. Breeder seed will be maintained by the North Dakota Agric. Exp. Stn., Fargo, ND 58105.

'Registered by the Crop Sci. Soc. Am. Published with the approval of the Director of the North Dakota Agric. Exp. Stn. as Journal Article No. 1168. Accepted 5 Apr. 1982.

${ }^{2}$ Professor and associate professor, Dep. of Agronomy; professor, Dep. of Plant Pathology; and associate professor, Dept. of Cereal Chemistry and Technology, respectively, North Dakota State Univ., Fargo, ND 58105 .

\section{REGISTRATION OF REDHILL BARLEY' (Reg. No. 180) \\ W. D. Graham, Jr., B. C. Morton, Jr., and G. C.
Kingsland $^{2}$}

'Redhill', C. I. 15830, is a winter type barley (Hordeum vulgare) developed and released in 1979 by the South Carolina Agricultural Experiment Station ${ }^{3}$. It originated from the cross of Tex. 64D2445/SC601098 made in 1968 and was selected as a single head row in the $\mathrm{F}_{6}$ generation. Redhill was tested as SC723232 in the Uniform Winter Barley Nursery (Semihardy cultivars) where it was first entered in 1978-1979. It was tested in South Carolina yield tests beginning in 1977 .

Redhill is an early maturing cultivar that is particularly suited for double cropping systems in the piedmont regions of the southeastern winter barley production areas. It is 7 to 10 days earlier and $5 \mathrm{~cm}$ taller than 'Keowee' under South Carolina test conditions. Redhill has stiff straw and is resistant to prevalent races of leaf rust, incited by Puccinia hordei Otth. and powdery mildew, incited by Erysiphe graminis DC. f. sp. hordei Em. Marchal. Reaction to scald, incited by Rhynchosporium secalis (Oud.) $\mathrm{J}$. J. Davis, is intermediate with moderate resistance being the more prevalent reaction.

Redhill is six-rowed with semismooth awns. The awns are only on the center row of spikelets and are variable in length. Early growth is semiprostrate. Basal leaf sheath is green with hairs; upper leaf sheath is waxy with white auricles and leaves that are semierect. Collars are closed. The distance from flag leaf to spike is 20 to $23 \mathrm{~cm}$ and the neck is straight. The basal rachis internode is short, and straight to slightly curved. The lateral kernels do not overlap. The spike is parallel in shape, erect, short to midlong, and lax to medium dense with a hairy rachis. Glume awns are equal to length of the glume, rough, and have hairs in a band. Lemma teeth are few on lateral nerves. There is a depression on the lemma base; rachilla is long haired and < $10 \%$ abortive. The covered kernels have a white aleurone and slightly wrinkled hulls.

Breeder seed of Redhill will be maintained by the Dep. of Agronomy and Soils, Clemson Univ., Clemson, SC 29631.

'Registered by the Crop Sci. Soc. of Am. Contribution of the South Carolina Agric. Exp. Stn., Clemson, SC 29631. Published with the approval of the Director of the South Carolina Agric. Exp. Stn. as Technical Paper No. 2018. Accepted 19 Apr. 1982.

${ }^{2}$ Professor and agricultural science associate III, agronomy and soils, and associate professor of plant pathology and physiology, Clemson Univ., Clemson, SCO 29631

${ }^{3}$ Graham, Jr., W. D., B. C. Morton, Jr., and G. C. Kingsland. 1982. Redhill barley: A new winter cultivar for the southeast. South Carolina Agric. Exp. Stn. Circular 190. January 1982. 